\title{
A Comparison of Cost in Organic and Conventional Olive Oil Production in Greece
}

\author{
Evangelia PANAGODIMOU ${ }^{1}$, Ioannis ROUSSIS ${ }^{1}$, Christos T. PAPADAS ${ }^{2}$, Dimitrios BILALIS ${ }^{*}$ \\ ${ }^{1}$ Agricultural University of Athens, School of Agriculture, Engineering and Environmental Sciences, \\ Department of Crop Science, Laboratory of Agronomy, 75 Iera Odos Str., 11855 Athens, Greece \\ ${ }^{2}$ Agricultural University of Athens, School of Food, Biotechnology and Development, Department of \\ Agricultural Economics and Rural Development, Laboratory of Rural Economic Development, 75 Iera \\ Odos Str., 11855 Athens, Greece \\ *corresponding author: bilalisdimitrios@gmail.com
}

BulletinUASVM Horticulture 76(1) / 2019

Print ISSN 1843-5254, Electronic ISSN 1843-5394

DOI:10.15835/buasvmcn-hort: 2018.0044

\begin{abstract}
An economic analysis of conventional and organic olive oil cultivation was examined in one of the most important olive-growing regions in Greece. Based on structured interviews and open-ended questions of 60 farmers from both organic and conventional systems, this study aimed to clarify the cost and returns of organic olive oil cultivation in comparison with conventional farming. Olive oil cultivation cost was calculated as $2.60 €$ $\mathrm{kg}^{-1}$ in organic and $2.25 € \mathrm{~kg}^{-1}$ in conventional system. The selling price for organic olive production was $4.19 €$ $\mathrm{kg}^{-1}$ compared to $3.63 € \mathrm{~kg}^{-1}$ for conventional production. Net profit from organic olive oil cultivation was 7,043.43 $€$ ha $^{-1}$, which was $3,664.58 €$ ha $^{-1}$ higher than the net profit from conventional cultivation. Finally, in both types of olive farming the results of financial analysis attested to a positive convenience; however, organic farming is more advantageous providing a financially competitive alternative to conventional.
\end{abstract}

Keywords: conventional farming, olive oil, organic farming, cultivation cost analysis

\section{Introduction}

Globally, more than 750 million olive trees are grown, $95 \%$ of them in the Mediterranean countries. Of European production, 93\% comes from Spain, Italy and Greece. Greece consists of the third largest producer of olive oil with more than 133 million olive trees, producing about 426 thousand tons of olive oil per year (FAO, 2018).

The available data for 2010 show that olive groves account for approximately 5 million hectares in the EU, and concentrated in Spain (50\%), Italy (26\%) and Greece (22\%). Average olive oil production in the EU has been 2.2 million tones representing $73 \%$ of world production. Spain, Italy, and Greece constitute almost the total EU olive oil production (97\%), with Spain producing nearly $62 \%$ of this amount (EC, 2012).

According to data collected by FAOSTAT, Greece produced an average of 344,615 tons of olive oil from 1993-2014 making it the third olive oil producing country in the world $(11 \%$ of total volume production) (FAO, 2018). It exports most of its olive oil to Italy and other countries including the United States of America, Canada, Japan, Australia, and China. Despite the high quantity and excellent quality of olive oil, Greek olive oil sector is unprofitable. In order to compete with the two sovereign countries, Italy and Spain, some structural changes must be made. 
Organic Agriculture, with its specific techniques, inputs, certifications, and markets, comprises not only an innovation but an integrated mix of long-term labor and knowledge intensive innovations (Santucci, 2007). The produced organic olive oil is usually extra virgin or virgin olive oil, products with exceptional taste and high nutritional value protecting consumers health. Olive cultivation is the most basic organic cultivation in Greece, mainly due to domestic soil and climatic conditions, the expertise developed on fertilization methods and the increased international demand for a high-quality olive oil. According to data from Greek Ministry of Rural Development and Food for the year 2010, dominant organic farming for Greece is the cultivation of olive with $56,970.1$ ha accounting for $18.4 \%$ of the total organic cultivation area (Greek Ministry of Rural Development and Food, 2018).

Considering the increasing trend of organic olive oil production in Greece, it is worthwhile to investigate to what extent organic olive farming in an important olive oil producing area could provide a financially competitive alternative to conventional olive oil production. The present study aimed to determine and analyze the costs of the organic and conventional olive oil cultivation by comparing agricultural practices and the farmers' attitudes to organic and conventional olive farming.

\section{Materials and Methods}

Aetolia-Acarnania is a regional unit in the geographical region of Central Greece and the administrative region of Western Greece. It is regarded as one of the most important olivegrowing regions in Greece (Greek Ministry of Rural Development and Food, 2018). It has a population of 210,802 inhabitants and an area of $5,461 \mathrm{~km}^{2}$ (ELSTAT, 2011). There are seven municipalities including Missolonghi, where the study was conducted. Olive farming constitutes one of the most important agricultural occupations in Aetolia-Acarnania, with 36.4\% of the agricultural area (excluding grasslands) in the region consisting of olive groves. The total olive cultivated land (conventional and organic) is estimated at 66,000 ha with 5.5 million olive trees ( $80 \%$ in organized olive groves). About $55 \%$ of these are used for olive oil production. In addition, the region is experiencing significant growth in
Organic Agriculture with the certified organic olive growers being about 300 (Greek Ministry of Rural Development and Food, 2018).

During the cultivation period 2016/17, a quantitative research was performed using structured interviews (face to face - a set of questions) and open-ended questions. The purpose of the questionnaires/interviews was to obtain information about the expenses and income of the farmers, the usage of fertilizers, pesticides and other agriculture practices under organic and conventional olive farming system. The selected sample was composed of 30 conventional and 30 certified organic farmers who are actively employed in the agricultural sector and especially in the olive oil production sector. In a comparative study of the cost of organic cultivation, the ideal sample of organic farms must logically include fully certified farmers (Tzouvelekas et al., 2001).

The economic results of the current research were calculated using the following formulas: Gross Annuity = Total Sales Value + Total Subsidies (1) Net Profit = Gross Annuity - Production Costs Gross Profits = Gross Annuity - Total Variable Costs (3) Agricultural Farmer's Income = Gross Annuity - Total Apparent Costs

Net Annuity = Net Profit + Interest + Rent

Capital Efficiency (\%) = Net Annuity / Average Invested Capital

\section{Results and Discussion}

Olive oil cultivation cost was calculated as 2.60 $€ \mathrm{~kg}^{-1}$ in organic and $2.25 € \mathrm{~kg}^{-1}$ in conventional system (Tab. 1). This is in full accordance with a previous study of Tzouvelekas et al. (2001), who found that the olive production cost was 4.35 and $3.74 € \mathrm{~kg}^{-1}$ in organic and conventional production, respectively. The difference between the cost values of the present study and the study of Tzouvelekas et al. (2001) is mainly due to the different currency. Tzouvelekas et al. (2001) performed the cost analysis using the Drachma, which was the currency used in Greece and replaced by the Euro in January 2002. The composition of costs between these types of cropping systems are very different. Concerning conventional production, it involves much higher chemical costs, while organic systems substitutes field operations for chemicals and incurred much higher fuels, repairs and labors (Sgroi et al., 2015). In addition, non-production costs are higher in organic systems, because of 
Table 1. Annual production cost of organic and conventional olive production

\begin{tabular}{|c|c|c|}
\hline Production Items & $\begin{array}{l}\text { Organic } \\
(€ / \text { ha })\end{array}$ & $\begin{array}{c}\text { Conventional } \\
(€ / \mathrm{ha})\end{array}$ \\
\hline \multicolumn{3}{|l|}{ A. Land } \\
\hline i. Land rent & 171.15 & 148.37 \\
\hline \multicolumn{3}{|l|}{ B. Labor } \\
\hline i. Farmer's family labor & $1,088.02$ & 997,43 \\
\hline ii. Outside the farmer's family labor & 727.63 & 786.94 \\
\hline $\begin{array}{c}\text { iii. Insurance contributions to Unified } \\
\text { Social Security Fund (EFKA) }\end{array}$ & 48.90 & 27.73 \\
\hline iv. Interests & 20.44 & 21.64 \\
\hline \multicolumn{3}{|l|}{ C. Capital } \\
\hline \multicolumn{3}{|l|}{ i. Fixed Capital } \\
\hline a) Amortization & 810.79 & 896.27 \\
\hline b) Fixed capital interests & 464.29 & 593.47 \\
\hline c) Maintenance & 103.99 & 121.16 \\
\hline d) Insurance premiums & 131.62 & 108.31 \\
\hline $\begin{array}{c}\text { e) Maintenance \& Insurance } \\
\text { premiums interests }\end{array}$ & 6.48 & 6.31 \\
\hline \multicolumn{3}{|l|}{ ii. Circulating Capital } \\
\hline Consumables (Seeds, Fertilizers, Fuels etc.) & $1,466.99$ & $1,168.09$ \\
\hline $\begin{array}{l}\text { b) Contributions to Greek } \\
\text { Agricultural Insurance } \\
\text { Organization (ELGA) }\end{array}$ & 48.90 & 74.18 \\
\hline c) Third party services & 404.31 & 296.74 \\
\hline d) Other costs & 202.12 & 222.55 \\
\hline e) Circulating capital interest & 122.25 & 48.44 \\
\hline \multirow{2}{*}{ Total Production Costs } & $5,817.88$ & $5,517.63$ \\
\hline & 2.60 & 2.25 \\
\hline
\end{tabular}

the expensive organic certification and additional training for the farmers (Artukoglu et al., 2012). Generally, in olive production, labor is the costliest factor in olive production as the family labor force accounts for $43-57 \%$ of the total cost and paid labor for $10-17 \%$. Other significant factors relate to specific costs $(10-16 \%)$ and depreciation (617\%) (EC, 2012).

When selling prices were examined in both types of cropping systems, it was determined that the farmers sold their olive over the unit cost of production. Specifically, the selling price for organic olive production was $4.19 € \mathrm{~kg}^{-1}$ compared to $3.63 € \mathrm{~kg}^{-1}$ for conventional production (data not shown). Both kind of production had profit, but the profit of organic production was bigger. Olive selling price was $61.2 \%$ higher that the production cost in organic system.

Net profit from organic olive oil cultivation was $7,043.43 €$ ha $^{-1}$, which was 3,664.58 € ha ${ }^{-1}$ higher than the net profit from conventional cultivation (Tab. 2). This result illustrated that organic olive production was economically more profitable for farmers if compared to conventional production, even though the organic system generated lower yields (8263 $\mathrm{kg} \mathrm{ha}^{-1}$ ) than the conventional (9151 $\mathrm{kg} \mathrm{ha}^{-1}$ ). The selling price difference for olive between organic and conventional production as well as the extra governmental subsidies for organic production were the major factors contributing to the higher profitability in organic olive farming (Sgroi et al., 2015).

We demonstrated that in both types of olive farming the results of financial analysis attested to a positive convenience; however, organic farming is more advantageous providing a financially competitive alternative to conventional olive farming. Profitability was higher in the organic system primarily due to public subsidies and to selling prices which are $15.4 \%$ higher if compared 
Table 2. Annual economic outcomes of organic and conventional olive production

\begin{tabular}{ccc}
\hline Economic outcomes & $\begin{array}{c}\text { Organic } \\
(€ / \mathrm{ha})\end{array}$ & $\begin{array}{c}\text { Conventional } \\
(€ / \text { ha })\end{array}$ \\
\hline Gross annuity & $12,861.29$ & $8,896.19$ \\
\hline Net profit & $7,043.43$ & $3,378.85$ \\
\hline Gross profits & $9,868.67$ & $6,277.59$ \\
\hline Agricultural farmer's income & $8,793.81$ & $7,134.63$ \\
\hline Net annuity & $7,876.94$ & $4,224.51$ \\
\hline Capital efficiency (\%) & $27.7 \%$ & $11.0 \%$ \\
\hline
\end{tabular}

to conventional in olive prices, offsetting the lower yields in comparison to the conventional system.

\section{References}

1. Artukoglu MM, Olgun FA, Adanacioglu H (2012). An economic analysis of organic and conventional olive production: Case of Turkey. Journal of Ege University Faculty of Agriculture, Turkey, 49(3): 243-247.

2. European Commission (EC). Directorate-General for Agriculture and Rural Development. Economic analysis of the EU olive oil sector (2012). https://ec.europa.eu/ agriculture/olive-oil/economic-analysis_en.pdf. Accessed 09.09.18.

3. Food and Agriculture Organization of the United Nations (FAO). Food and Agriculture Organization Corporate Statistical Database (FAOSTAT) (2018). http://www.fao. org/ faostat/en/\#data/QC. Accessed 08.09.18.

4. Greek Ministry of Rural Development and Food. Organic Farming in Greece (in Greek) (2018).
5. Hellenic Statistical Authority (ELSTAT). Population and social conditions: Demographic characteristics (2011). http://www.statistics.gr/en/statistics/-/publication/ SAM03. Accessed 08.09.18

6. http://www.minagric.gr/index.php/el/for-farmer-2/ biologikgeorgiaktinotrofia. Accessed 08.09.18

7. Santucci FM (2007). Organic olive and oil production within the context of rural development. Which services are required and who can supply them? http://orgprints. org/13532/1/ESEE07-oil-Fulltextrev.pdf. Accessed 08.09 .18

8. Sgroi F, Foderà M, Di Trapani AM, Tudisca S, Testa R (2005). Cost-Benefit Analysis: A comparison between conventional and organic olive growing in the Mediterranean Area. Ecological Engineering, 82: 542546.

9. Tzouvelekas V, Pantzios CJ, Fotopoulos C (2001). Technical efficiency of alternative farming systems: the case of Greek organic and conventional olive-growing farms. Food Policy, 26(6): 549-569. 